\title{
Effect of tetrasodium pyrophosphate concentration and cooking time on the physicochemical properties of process cheese
}

\author{
N. Shirashoji, ${ }^{\dagger} \ddagger$ H. Aoyagi, $†$ J. J. Jaeggi, $\ddagger$ and J. A. Lucey $\ddagger^{1}$ \\ *Food Research \& Development Laboratory, Morinaga Milk Industry Co., Ltd., 1-83, 5-Chome Higashihara, Zama, Kanagawa 228-8583 Japan \\ †Life Sciences and Bioengineering, Graduate School of Life and Environmental Sciences, University of Tsukuba, 1-1-1 Tennodai, Tsukuba, \\ Ibaraki 305-8572 Japan \\ ¥Wisconsin Center for Dairy Research, University of Wisconsin-Madison, 1605 Linden Drive, Madison 53706
}

\section{ABSTRACT}

Tetrasodium pyrophosphate (TSPP) is widely used as an emulsifying salt (ES) in process cheese. Previous reports have indicated that TSPP exhibits some unusual properties, including the gelation of milk proteins at specific ES concentrations. We studied the effect of various concentrations $(0.25-2.75 \%)$ of TSPP and cooking times (0-20 min) on the rheological, textural, and physical properties of pasteurized process Cheddar cheese using a central composite rotatable experimental design. Cheeses were made with a constant $\mathrm{pH}$ value to avoid $\mathrm{pH}$ as a confounding factor. Modeling of the textural properties of process cheese made with TSPP exhibited complex behavior, with polynomial models (cubic) giving better predictions (higher coefficient of determination values) than simpler quadratic models. Meltability indices (degree of flow from the UW MeltProfiler (University of Wisconsin-Madison), loss tangent value at $60^{\circ} \mathrm{C}$ from rheological testing, and Schreiber melt area) initially decreased with increasing TSPP concentrations, but above a critical ES concentration $(\sim 1.0 \%)$ meltability increased at higher TSPP concentrations. The storage modulus values measured at $70^{\circ} \mathrm{C}$ for process cheese initially increased with increasing TSPP concentration, but above a concentration of $1 \% \mathrm{ES}$, the storage modulus values decreased. Cooking time had little effect on the various melting or rheological properties. With an increase in TSPP concentration, the insoluble $\mathrm{Ca}$ and $\mathrm{P}$ contents increased, suggesting that TSPP addition resulted in the formation of insoluble calcium pyrophosphate complexes; some of which were likely associated with caseins. A portion of the added TSPP remained in the soluble phase. The acid-base buffering profiles also indicated that calcium pyrophosphate complexes were formed in cheese made with TSPP. In milk systems, low levels of

Received January 29, 2016.

Accepted May 27, 2016.

${ }^{1}$ Corresponding author: jalucey@facstaff.wisc.edu
TSPP have been shown to induce protein crosslinking and gelation, whereas at higher TSPP concentrations milk gelation was inhibited due to excessive charge repulsion from these calcium pyrophosphate complexes. We hypothesized that a similar phenomenon was occurring in our process cheese, resulting in the initial reduction in meltability with TSPP addition due to protein crosslinking, but at higher TSPP levels meltability increased due to excessive charge repulsion.

Key words: emulsifying salt, texture, meltability

\section{INTRODUCTION}

Process cheese manufacturing involves the heating or shearing of natural cheese in the presence of calcium chelating salts (phosphates and citrates) that are commonly referred to as emulsifying salts (ES; Berger et al., 1998; Maurer-Rothmann and Scheurer, 2005). Heating of natural cheese in the absence of ES causes oiling off, which is the separation of fat from the rest of the cheese mass (Lucey et al., 2011). These ES act by disrupting the insoluble Ca-phosphate nanoclusters that are important cross-links for the stability of the caseins (Horne, 1998), thereby dispersing the insoluble casein matrix of natural cheese (Guinee et al., 2004).

Various factors affect the properties of process cheese, including composition (moisture, protein, or fat content), $\mathrm{pH}$, maturity and types of natural cheeses, cooking temperature or time, and cooling rate after cooking (Guinee et al., 2004). The precise effect of the ES used is the least well-understood variable in process cheese manufacturing, and made more complex by the common use of mixtures of different types of ES, in various proprietary ratios. Over the years, studies have focused on the effects of single, or mixtures, of ES on various types of process cheese (Templeton and Sommer, 1930; Gupta et al., 1984; Cavalier-Salou and Cheftel, 1991; Awad et al., 2002; Dimitreli et al., 2005; Sádlíková et al., 2010; Nagyová et al., 2014). However, one significant confounding factor not addressed in most of these studies is that the addition of ES also alters $\mathrm{pH}$, and 
the $\mathrm{pH}$ value of process cheese has a marked effect on its physical properties (Marchesseau et al., 1997; Mulsow et al., 2007; Lu et al., 2008; Lucey et al., 2011). A couple of studies on ES mixtures did adjust samples to a constant pH (Nagyová et al., 2014; Salek et al., 2015). Consequently, detailed studies where $\mathrm{pH}$ is excluded as a possible factor are needed to explore the mechanisms by which the different types of individual ES affect the properties of process cheese.

Cooking time is well known to affect the properties of process cheese (Rayan et al., 1980). Heat and shearing during cooking could also act synergistically with ES to better disperse the caseins during process cheese manufacturing (Mulsow et al., 2007). It has also been reported that with longer cooking times, for some types of ES, a thickening or increase in viscosity, commonly referred to as creaming, can be observed (Meyer, 1973; Berger et al., 1998; Kawasaki, 2008).

Tetrasodium pyrophosphate (TSPP) is a well-known Ca chelating agent and is commonly used in the food industry as a binding agent for meats, a tartar control agent in toothpaste, and an emulsifier for process cheese. Several studies have reported on the characteristics of TSPP such as its buffering ability (Guinee et al., 2004; Maurer-Rothmann and Scheurer, 2005; $\mathrm{Lu}$ et al., 2008), Ca-sequestering ability (Carić et al., 1985; Guinee et al., 2004), and ability to disperse casein (Dimitreli et al., 2005; Cunha and Viotto, 2010). Lucey et al. (2011) indicated that TSPP is an ES with strong buffering and creaming ability, and moderately strong Ca-binding ability. Various studies (Gupta et al., 1984; Cavalier-Salou and Cheftel, 1991; Dimitreli et al., 2005) also reported that addition of TSPP to cheese analog, or process cheese, resulted in higher $\mathrm{pH}$ values. Mizuno and Lucey (2007) investigated the influence of TSPP on some physical properties of caseins using a reconstituted milk protein concentrate solution adjusted to pH 5.8. Mizuno and Lucey (2007) reported that low concentrations of TSPP effectively dispersed caseins, whereas at some critical concentrations of TSPP gelation of caseins was observed in solution during storage at room temperature. Addition of high concentrations of TSPP to the milk protein solutions dispersed caseins, but no gels were observed during storage due to excessive electrostatic repulsion (Mizuno and Lucey, 2007). To our knowledge, no studies exist on the effect of TSPP addition on the state of $\mathrm{Ca}$ in process cheese. The objectives of the current study were to investigate the effect of TSPP concentrations and cooking time on the rheological and textural properties of pasteurized process Cheddar cheese. Another objective was to determine the state of $\mathrm{Ca}$ on process cheese made with TSPP that were adjusted to a constant $\mathrm{pH}$ to avoid the confounding effect of differences in $\mathrm{pH}$ values.

\section{MATERIALS AND METHODS}

In the current study, we used similar materials and methods as applied by our group in previous single ES studies; that is, where the effect of the trisodium citrate and sodium hexametaphosphate on properties of process cheese was studied (Shirashoji et al., 2006, 2010).

\section{Materials}

Four-month-old Cheddar cheese was obtained from Alto Dairy Cooperative. Cheeses used for this research had the following composition: moisture, $37 \%$; fat, $34 \%$; protein $26 \%$; $669 \mathrm{mg}$ of $\mathrm{Ca} / 100 \mathrm{~g}$ of cheese. The ES used was TSPP (ICL Performance Products LP, St. Louis, MO). The $\mathrm{pH}$ modifiers used were $50 \%$ sodium hydroxide (Fisher Scientific, Pittsburgh, PA) or $88 \%$ lactic acid (Brenntag Great Lakes LLC, Wauwatosa, WI).

\section{Process Cheese Manufacture}

Process cheeses were manufactured with a Blentech twinscrew cooker (Blentech Corp., Rohnert Park, CA) as described by Shirashoji et al. (2006, 2010). Cheddar cheese was grated by a meat grinder (Biro Manufacturing, Marblehead, OH). The TSPP $(0.25-2.75 \%)$ were added into grated cheese, mixed with water, and added to the cooker to avoid lumps of TSPP. Mixing was at $50 \mathrm{rpm}$ for $40 \mathrm{~s}$, then stirred at $100 \mathrm{rpm}$, and heated by direct steam injection $(87 \mathrm{kPa})$ for $200 \mathrm{~s}$; indirect steam was used to finish heating. The $\mathrm{pH}$ of the final products was adjusted by adding $50 \%$ sodium hydroxide or $88 \%$ lactic acid during premixing, but water addition was adjusted in those $\mathrm{pH}$-adjusted samples to maintain constant cheese moisture concentrations. After cooking to $80^{\circ} \mathrm{C}$, melted cheese was poured into $0.9-\mathrm{kg}$ pouches. The cheese blocks were vacuum sealed after cooling, then stored at $5^{\circ} \mathrm{C}$. All analyses were determined $7 \mathrm{~d}$ after manufacture.

\section{Rheological and Meltability Measurements}

Rheological properties of pasteurized process cheese were measured by dynamic small amplitude oscillatory rheology as described by Shirashoji et al. (2006, 2010). The storage modulus $\left(\mathbf{G}^{\prime}\right)$ and loss tangent $(\mathbf{L T})$ were determined by dynamic temperature ramp test. The cheese disks were heated from 5 to $85^{\circ} \mathrm{C}$ at the rate of $1^{\circ} \mathrm{C} /$ min with an applied strain of $0.5 \%$ and a frequency of $0.08 \mathrm{~Hz}$. Three replicates were measured for each cheese sample.

Texture profile analysis (TPA) was performed using a TA.XT2 Texture Analyzer (Texture Technologies 
Corp., Scarsdale, NY), as described by Shirashoji et al. (2006, 2010). For TPA measurement, cheese was compressed $80 \%$ of the original height at $5^{\circ} \mathrm{C}$. Both tests were measured with a cross-head speed of $0.8 \mathrm{~mm} / \mathrm{s}$ and replicated at least 5 times. Meltability and flow behavior of cheeses was evaluated using the modified Schreiber test (Muthukumarappan et al., 1999a) and the UW-Meltprofiler (University of Wisconsin-Madison) as described by Muthukumarappan et al. (1999b); these tests were replicated 4 times.

\section{Acid-Base Titration}

Acid-base titrations were performed to determine buffering capacity in cheese as described by Hassan et al. (2004). Acid-base buffering curves can be used to indicate changes in the concentration, or form, of insoluble calcium phosphate in milk or cheese (Lucey and Fox, 1993; Hassan et al., 2004; Mizuno and Lucey, 2005). Cheese homogenates, which dispersed $8 \mathrm{~g}$ of grated cheese in $40 \mathrm{~mL}$ of distilled water using a blender, were titrated from the initial $\mathrm{pH}$ to 3.0 with $0.5 \mathrm{~N} \mathrm{HCl}$ and then back titrated to $\mathrm{pH} 8.0$ with $0.5 \mathrm{~N}$ $\mathrm{NaOH}$. Buffering indices $(\mathrm{dB} / \mathrm{dpH})$ were calculated for each addition of titrant, and buffering curves derived by plotting these indices as a function of $\mathrm{pH}$.

\section{Composition Analysis}

Cheeses were analyzed for moisture, fat, protein (Marshall, 1992), and $\mathrm{pH}$ by insertion of a $\mathrm{pH}$ probe at room temperature (pH meter 420A, Orion Research, Beverley, MA). The total $\mathrm{Ca}$ and $\mathrm{P}$ and insoluble $\mathrm{Ca}$ and $\mathrm{P}$ contents of cheese samples were measured as de- scribed by Shirashoji et al. (2006). In the insoluble Ca and $\mathrm{P}$ analysis test, the pellet (precipitate) weight of the cheese dispersion after the centrifugation step was recorded to indicate the degree of casein peptization or dispersion (Cunha and Viotto, 2010).

\section{Experimental Design and Statistical Analysis}

A central composite rotatable design and response surface methodology were employed to study the effects of concentration of ES (wt/wt) and holding (cooking) time on the functional properties of pasteurized process Cheddar cheese as described by Shirashoji et al. (2006, 2010). A 2-level factorial experimental design was chosen to study the effects of the independent variables (ES concentration and holding time) with 2 star points ( $\alpha=1.414$ ) and 4 replicates of the center point (Table 1). The coded variables were related to the real units by equations [1] and [2]:

Coded concentration of $\mathrm{ES}=\frac{\text { concentration of } \mathrm{ES}(\%)-1.5}{0.884}$,

and

$$
\text { Coded holding time }=\frac{\text { holding time }(\min )-10}{7.071} .
$$

The $\alpha$ term reflects the axial distance in a rotatable design from the center point to the farthest away points (star) of the design. The value of $\alpha$ is the square root of the number of factors in the design $(\sqrt{2}=1.414)$. In

Table 1. Values of independent variables of each experiment in coded and actual values for the central composite experimental design

\begin{tabular}{|c|c|c|c|c|}
\hline \multirow[b]{2}{*}{$\begin{array}{l}\text { Treatment } \\
\text { no. }\end{array}$} & \multicolumn{2}{|c|}{ Coded values } & \multicolumn{2}{|c|}{ Actual values } \\
\hline & $\begin{array}{l}\text { Concentration of } \\
\text { emulsifying salt }\end{array}$ & $\begin{array}{l}\text { Holding } \\
\text { time }\end{array}$ & $\begin{array}{l}\text { Concentration of } \\
\text { emulsifying salt (\%) }\end{array}$ & $\begin{array}{l}\text { Holding } \\
\text { time (min) }\end{array}$ \\
\hline 1 & 0 & 0 & 1.50 & 10.0 \\
\hline 2 & -1 & -1 & 0.62 & 2.90 \\
\hline 3 & 0 & 0 & 1.50 & 10.0 \\
\hline 4 & +1 & +1 & 2.38 & 17.1 \\
\hline 5 & +1 & -1 & 2.38 & 2.90 \\
\hline 6 & 0 & $+\alpha^{*}$ & 1.50 & 20.0 \\
\hline 7 & 0 & $-\alpha$ & 1.50 & 0.0 \\
\hline 8 & $-\alpha$ & 0 & 0.25 & 10.0 \\
\hline 9 & 0 & 0 & 1.50 & 10.0 \\
\hline 10 & $+\alpha$ & 0 & 2.75 & 10.0 \\
\hline 11 & -1 & +1 & 0.62 & 17.1 \\
\hline 12 & 0 & 0 & 1.50 & 10.0 \\
\hline
\end{tabular}


equation [1], the value 1.5 in the numerator represents the central point of the design $(1.5 \% \mathrm{ES})$, and the value 10 in the numerator equation [2] represents the central point of this design (10 min of holding time). To obtain the other values in the design, we first selected the lowest value; for example, with holding time, the lowest value was $0 \mathrm{~min}$. Thus, the distance in real units to $\alpha$ (1.414) was 10, and the distance from the center point to the 1.0 coded value in real units was $10 / 1.414=$ 7.071 (value in the denominator). Thus, equations [1] and [2] allow for the conversion of the coded values used in the statistical design into the real or experimental conditions/values.

Results were analyzed by stepwise regression using the Statgraphics program (version 5.1 plus, Manugistics, Rockville, MD). Dependent variables were estimated using polynomial models. Third-order models (cubic polynomials including the main effects, their interactions, and cubic terms to account for curvature in the responses) were applied for several variables to describe the complicated behavioral responses to ES concentration and holding time. Quadratic (second order) models were also evaluated but had poorer fits. Stepwise regression was used to eliminate insignificant factors $(F$-value $<4)$ using backward selection (Montgomery, 2001).

\section{RESULTS}

\section{Composition}

Oiling off, or moisture separation, was not observed during the manufacture or storage of the process cheese samples. The $\mathrm{pH}$ values for the various process cheese samples ranged from 5.56 to 5.67, and the range of moisture contents was 37.5 to $40.3 \%$ (Table 2). The variation in $\mathrm{pH}$ values was quite narrow; in our experience, this variation should not have a major effect on the functional properties of the cheeses. Treatment 12 had a higher moisture content (40.3\%); however, this sample was one of the center points in the experimental design, and center points were replicated 4 times, so any variation would be factored into the statistical analysis.

\section{Rheological and Textural Properties}

The effect of the ES concentration on rheological properties of process cheese is shown in Figure 1; holding time was $10 \mathrm{~min}$ for all samples. No oiling off was observed during rheological testing. The rheological properties of the natural Cheddar cheese that was used to manufacture process cheese was also shown for comparison purposes. At low temperatures $\left(<30^{\circ} \mathrm{C}\right)$, we noted little apparent differences in the $\mathrm{G}^{\prime}$ values (Figure 1a) or LT profiles (Figure 1b). Between 35 and $85^{\circ} \mathrm{C}$, the $\mathrm{G}^{\prime}$ profile of the process cheese with the lowest ES concentration (i.e., $0.25 \%$ ) was lower than that of other process cheese samples and appeared to exhibit a similar trend to the $\mathrm{G}^{\prime}$ profile for natural Cheddar cheese, at least until $\sim 70^{\circ} \mathrm{C}$. At higher temperatures $\left(>70^{\circ} \mathrm{C}\right)$ the $\mathrm{G}^{\prime}$ values for natural cheese increased, whereas the $\mathrm{G}^{\prime}$ values for the process cheese made with $0.25 \%$ TSPP continued to decrease. At temperatures $>40^{\circ} \mathrm{C}$, the highest $\mathrm{G}^{\prime}$ values were observed in process cheese made with $1.50 \%$ ES concentration, and its $\mathrm{G}^{\prime}$ values hardly changed with increasing temperature in contrast to the other process cheese where $\mathrm{G}^{\prime}$ values continued to decrease (Figure 1a). At temperatures $>40^{\circ} \mathrm{C}$, process cheese made with $1.5 \%$ ES had the lowest $\mathrm{LT}$ values (Figure $1 \mathrm{~b}$ ). The highest $\mathrm{LT}$ values were observed in process cheese made $2.75 \%$ ES concentration.

Statistical analysis of the effect of ES concentration and cooking time on the rheological and physical properties of process cheese are shown in Table 3. Highly significant prediction models were obtained for the $\mathrm{G}^{\prime}$ values at $70^{\circ} \mathrm{C}\left(\mathrm{R}^{2}=0.81\right)$ and $\mathrm{LT}$ values at $60^{\circ} \mathrm{C}\left(\mathrm{R}^{2}\right.$ $=0.98$ ) (Table 3 ). Holding time did not significantly influence the $\mathrm{G}^{\prime}$ values at $70^{\circ} \mathrm{C}$ or the $\mathrm{LT}$ values at $60^{\circ} \mathrm{C}$. Response surface plots for the $\mathrm{G}^{\prime}$ values at $70^{\circ} \mathrm{C}$ and LT values at $60^{\circ} \mathrm{C}$ are shown in Figure $2 \mathrm{a}$ and Figure $2 \mathrm{~b}$, respectively. The response surface plot for $\mathrm{G}^{\prime}$ values at $70^{\circ} \mathrm{C}$ indicated that the $\mathrm{G}^{\prime}$ values initially increased with increasing ES concentration, but above about $1 \%$ ES the $\mathrm{G}^{\prime}$ values at $70^{\circ} \mathrm{C}$ decreased (Figure 2a). The opposite trend was seen in the response surface plot for the $\mathrm{LT}$ values at $60^{\circ} \mathrm{C}$, with $\mathrm{LT}$ values initially decreasing with an increase in ES concentration, but at ES concentrations $>1 \%$, the LT values at $60^{\circ} \mathrm{C}$ increased (Figure 2b).

Table 2. Composition of process cheese made with tetrasodium pyrophosphate for each experimental treatment $(\mathrm{n}=2)$

\begin{tabular}{llcc}
\hline $\begin{array}{l}\text { Treatment } \\
\text { no. }\end{array}$ & $\mathrm{pH}$ & $\begin{array}{c}\text { Moisture } \\
(\%)\end{array}$ & $\begin{array}{c}\text { Fat } \\
(\%)\end{array}$ \\
\hline 1 & 5.56 & 39.65 & 32.40 \\
2 & 5.62 & 39.51 & 32.81 \\
3 & 5.65 & 38.43 & 32.18 \\
4 & 5.67 & 37.50 & 31.71 \\
5 & 5.65 & 38.01 & 32.72 \\
6 & 5.66 & 38.50 & 32.63 \\
7 & 5.60 & 38.89 & 32.09 \\
8 & 5.59 & 39.53 & 32.66 \\
9 & 5.63 & 38.75 & 32.45 \\
10 & 5.66 & 39.11 & 31.25 \\
11 & 5.61 & 39.93 & 32.21 \\
12 & 5.60 & 40.31 & 31.68 \\
\hline
\end{tabular}




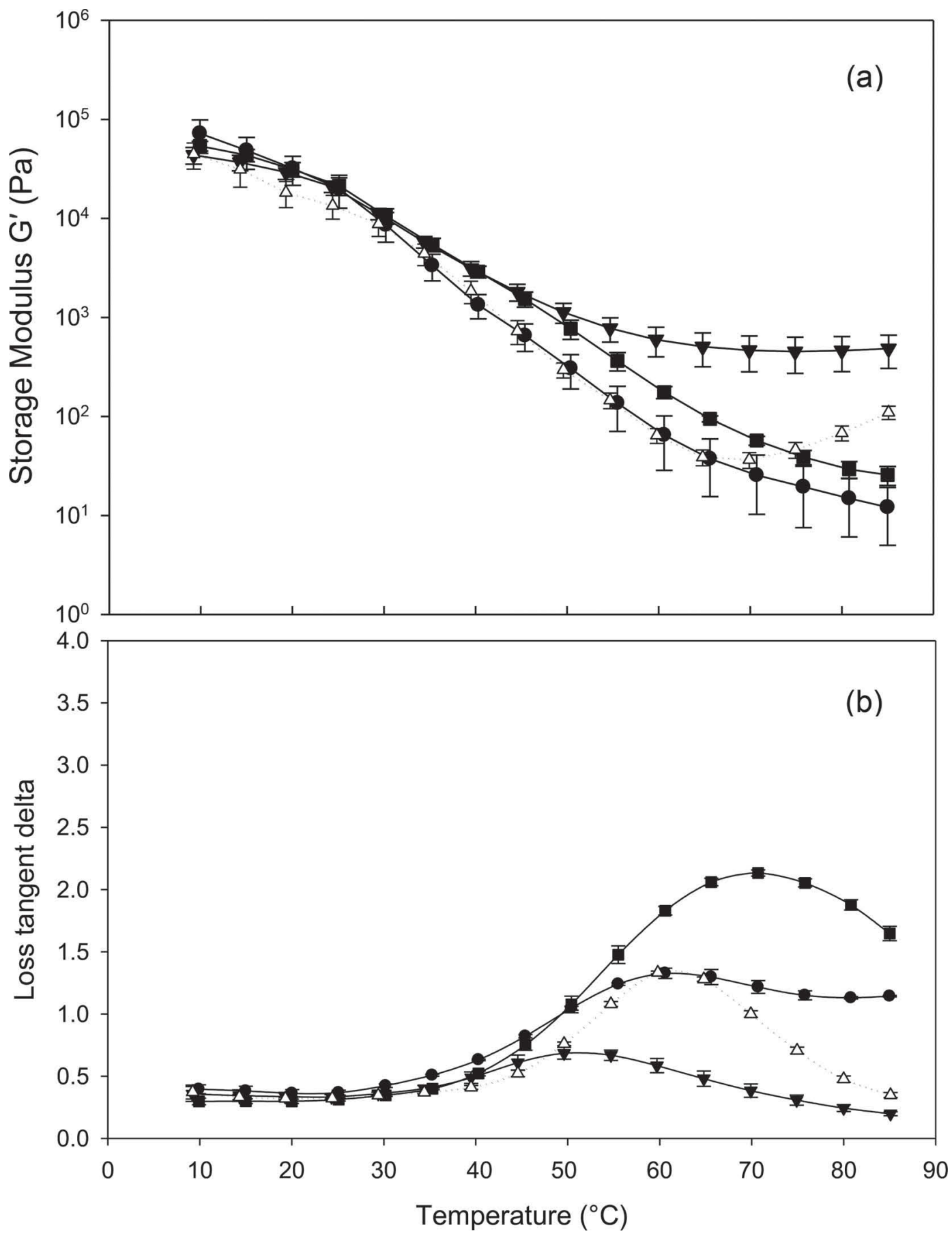

Figure 1. Storage modulus, $\mathrm{G}^{\prime}$ (a) and loss tangent (b), as a function of temperature for process cheeses made with various concentrations of tetrasodium pyrophosphate and natural Cheddar cheese as an ingredient $(\Delta)$. Tetrasodium pyrophosphate concentrations: $0.25(\bullet), 1.50(\mathbf{\nabla})$, and $2.75 \%(\mathbb{\square})$. Holding time was 10 min for all process cheese samples. The data represents means $(\mathrm{n}=3)$ whereas the error bars represent the standard deviation.

No significant prediction model $\left(\mathrm{R}^{2}=0.51\right)$ was observed for the TPA hardness values. We found a weak trend of TPA hardness increasing at low ES concentrations, but decreasing at higher ES levels.

\section{Meltability}

Melting profiles, obtained by the UW-Meltprofiler, for process cheese made with various ES concentrations 
Table 3. Polynomial models describing storage modulus $\left(\mathrm{G}^{\prime}\right)$ at $70^{\circ} \mathrm{C}$, loss tangent $(\mathrm{LT})$ at $60^{\circ} \mathrm{C}$, degree of flow (DOF) at $60^{\circ} \mathrm{C}$ from UW-Meltprofiler (University of Wisconsin-Madison). Schreiber melt area, insoluble $\mathrm{Ca}$ as a percentage of total $\mathrm{Ca}$, insoluble $\mathrm{P}$ as a percentage of total $\mathrm{P}$, insoluble $\mathrm{P}$ content, and pellet weight

\begin{tabular}{|c|c|c|c|c|}
\hline Dependent variables & $\begin{array}{l}\text { Independent } \\
\text { variable }^{1}\end{array}$ & Coefficient & $\begin{array}{c}\mathrm{R}^{2} \\
\text { (adjusted) }\end{array}$ & $P$-value \\
\hline $\mathrm{G}^{\prime}$ at $70^{\circ} \mathrm{C}$ & $\begin{array}{l}\text { Constant } \\
\text { ESC }^{* *} \\
\text { ESC }^{2 *} \\
\text { ESC }^{3 *}\end{array}$ & $\begin{array}{r}584.1 \\
-663.3 \\
-247.8 \\
338.7\end{array}$ & 0.81 & $<0.001$ \\
\hline Loss tangent at $60^{\circ} \mathrm{C}$ & $\begin{array}{l}\text { Constant } \\
\mathrm{ESC}^{*} \\
\mathrm{ESC}^{2 * * *} \\
\mathrm{ESC}^{3 * * *}\end{array}$ & $\begin{array}{r}0.5761 \\
0.6352 \\
0.4761 \\
-0.2287\end{array}$ & 0.98 & $<0.001$ \\
\hline Degree of flow & $\begin{array}{l}\text { Constant } \\
\text { ESC }^{* * *} \\
\text { ESC }^{2 * *} \\
\text { ESC }^{3 * * *}\end{array}$ & $\begin{array}{r}37.25 \\
34.50 \\
15.17 \\
-17.40\end{array}$ & 0.93 & $<0.001$ \\
\hline Schreiber melt area & $\begin{array}{l}\text { Constant } \\
\text { ESC }^{* *} \\
\text { ESC }^{2 *} \\
\text { ESC }^{3 *}\end{array}$ & $\begin{array}{r}12.96 \\
7.761 \\
4.084 \\
-4.949\end{array}$ & 0.88 & $<0.001$ \\
\hline Pellet weight & $\begin{array}{l}\text { Constant } \\
\text { ESC }^{* * *} \\
\text { ESC }^{3 *} \\
\text { Holding time } \\
\text { 2** }\end{array}$ & $\begin{array}{c}7.791 \\
-7.396 \\
2.908 \\
-0.4284\end{array}$ & 0.96 & $<0.001$ \\
\hline Insoluble $\mathrm{Ca}$ (\% of total $\mathrm{Ca}$ ) & $\begin{array}{l}\text { Constant } \\
\text { ESC*** }\end{array}$ & $\begin{array}{c}82.87 \\
7.002\end{array}$ & 0.79 & $<0.001$ \\
\hline Insoluble P (mg per $100 \mathrm{~g}$ of cheese) & $\begin{array}{l}\text { Constant } \\
\mathrm{ESC}^{* * *} \\
\mathrm{ESC}^{2} \dagger\end{array}$ & $\begin{array}{c}570.3 \\
134.1 \\
27.92\end{array}$ & 0.91 & $<0.001$ \\
\hline Insoluble $\mathrm{P}(\%$ of total $\mathrm{P}$ ) & $\begin{array}{l}\text { Constant } \\
\text { ESC }^{* *} \\
\text { ESC }^{2 * *}\end{array}$ & $\begin{array}{c}73.33 \\
-4.184 \\
4.887\end{array}$ & 0.68 & $<0.005$ \\
\hline
\end{tabular}

and with the same holding time (10 min) are shown in Figure 3. The melt profile for the natural cheese used to manufacture process cheese is also shown for comparison purposes. Process cheese made with $0.25 \%$ TSPP softened at a lower temperature than other samples, whereas the process cheese sample made with $1.50 \%$ TSPP exhibited very limited flow at high temperature. Highly significant prediction models were obtained for the degree of flow at $60^{\circ} \mathrm{C}$ measured by the UW-Meltprofiler $\left(R^{2}=0.93\right)$ and Schreiber melt area $\left(R^{2}=0.88\right.$; Table 3). The response surface plot for the degree of flow at $60^{\circ} \mathrm{C}$ measured by the UW-Meltprofiler (Figure 2c) exhibited the lowest melt at $\sim 1.0 \%$ TSPP concentration. A similar trend was observed for the response surface plot for the Schreiber melt test (Figure 2d).

\section{Degree of Peptization and the Insoluble Ca and P Levels}

A highly significant prediction model was obtained for the pellet weight (related to the degree of casein peptization; $\mathrm{R}^{2}=0.96$; Table 3 ). The response surface plot for pellet weight indicated an increase in weight at $\sim 0.7 \%$ ES concentration (Figure 4a), indicating a decrease in degree of casein peptization. With higher ES concentrations, the pellet weight decreased indicating greater casein peptization. A highly significant prediction model was obtained for the levels of insoluble $\mathrm{Ca}$ in process cheese $\left(R^{2}=0.79\right)$. The response surface plot for insoluble $\mathrm{Ca}$ content as a percentage of total $\mathrm{Ca}$ is shown in Figure 4b. The insoluble Ca content increased as the TSPP concentration increased. No significant effect was observed for the holding time. Prediction equations were developed for the insoluble $\mathrm{P}$ content $\left(R^{2}=0.91\right)$ as well as the insoluble $P$ as a percentage of total $\mathrm{P}\left(\mathrm{R}^{2}=0.68\right.$; Table 3$)$. The response surface plot for the insoluble $\mathrm{P}$ content is shown in Figure 4c, and a similar trend was observed as with the insoluble $\mathrm{Ca}$ as a percentage of total Ca (Figure 4b). When the insoluble $\mathrm{P}$ content was expressed as a percentage of total $\mathrm{P}$, the proportion of insoluble $\mathrm{P}$ decreased with increasing ES levels (Figure 4d). This indicated that some of the added $\mathrm{P}$ from the ES remained in the soluble phase of process cheese. 


\section{Acid-Base Buffering Curves}

The acid-base titration curves of process cheese made with different concentrations of TSPP are shown in Figure 5. The acid-base buffering curves of the natural cheese used for process cheese manufacturing is shown in Figure 5a. Addition of $0.25 \%$ TSPP eliminated the buffering peak at $\mathrm{pH} \sim 6$ during addition of alkali to acidified samples (Figure 5b). With an increase in the concentration of ES, a new buffering peak was observed between $\mathrm{pH}$ values 4 to 5 during titration of acidified samples with alkali (Figure 5c-f). The buffering peak observed during acidification was also shifted to lower $\mathrm{pH}$ values with an increase in the concentration of TSPP. We found no significant difference in buffering curves of samples with different holding times (result not shown).

(a)

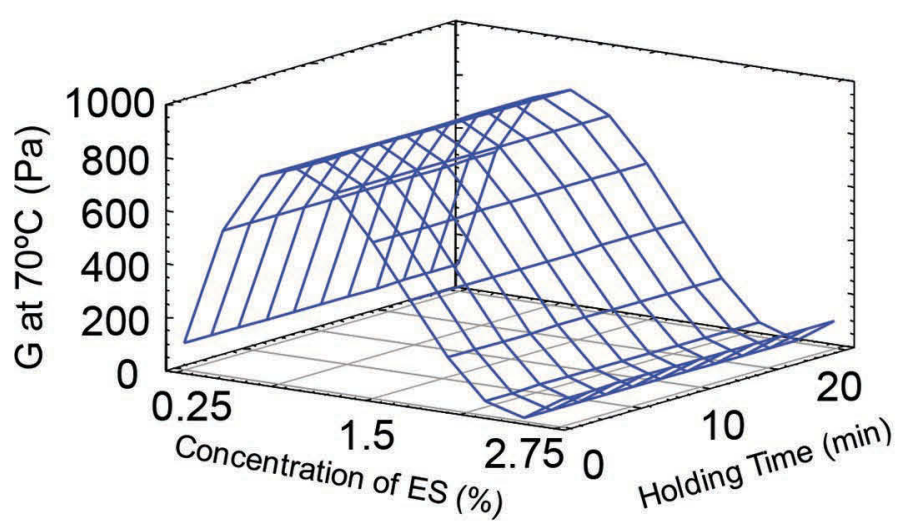

(c)

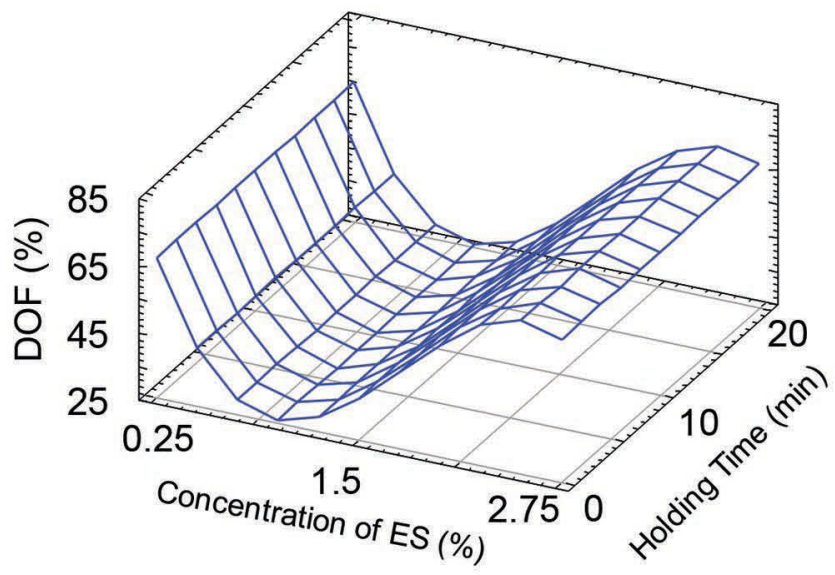

\section{DISCUSSION}

The addition of TSPP to natural cheese greatly affected the rheological and textural properties of process cheese including its meltability. The effect of TSPP on process cheese properties presumably reflect its strong Ca-binding ability as well as its ability to crosslink caseins (Mizuno and Lucey, 2005, 2007).

The addition of TSPP modified the status of Ca phosphate in process cheese. Addition of low levels of TSPP $(0.25 \%)$ eliminated the acid-base buffering peak that was observed at $\mathrm{pH} \sim 6$ during the back titration of natural cheese (Figure 5a), which indicated a modification in the status or form of the original insoluble calcium phosphate, even at very low levels of TSPP. At higher levels of TSPP, the acid-base buffering profiles were significantly altered and were similar to those

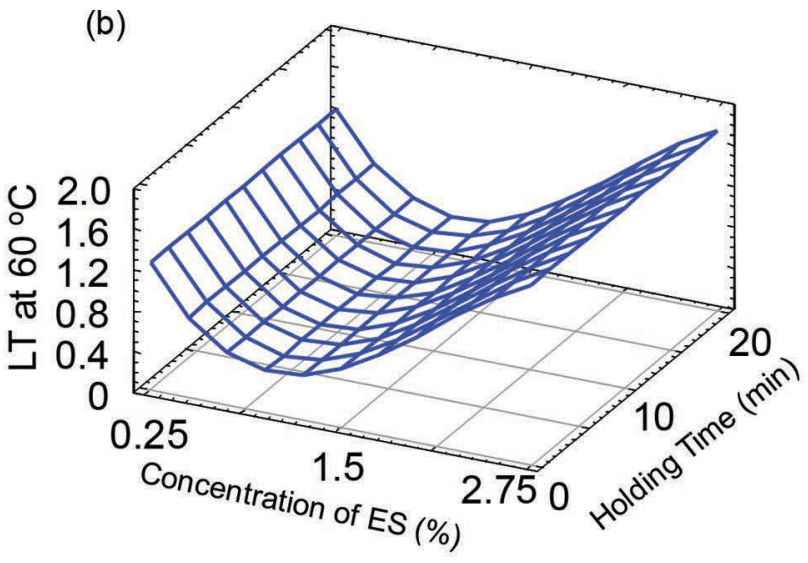

(d)

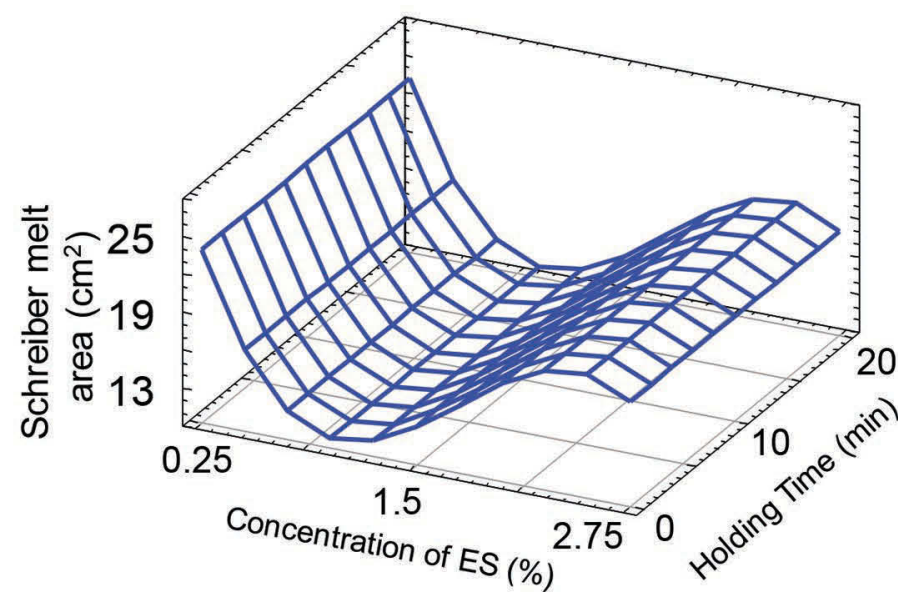

Figure 2. Response surface plots for the effect of concentrations of emulsifying salts (ES) and holding times on (a) storage modulus (G') at $70^{\circ} \mathrm{C}$, (b) loss tangent (LT) at $60^{\circ} \mathrm{C}$, (c) degree of flow (DOF) at $60^{\circ} \mathrm{C}$ from the UW-Meltprofiler (University of Wisconsin-Madison), and (d) Schreiber melt area. Color version available online. 


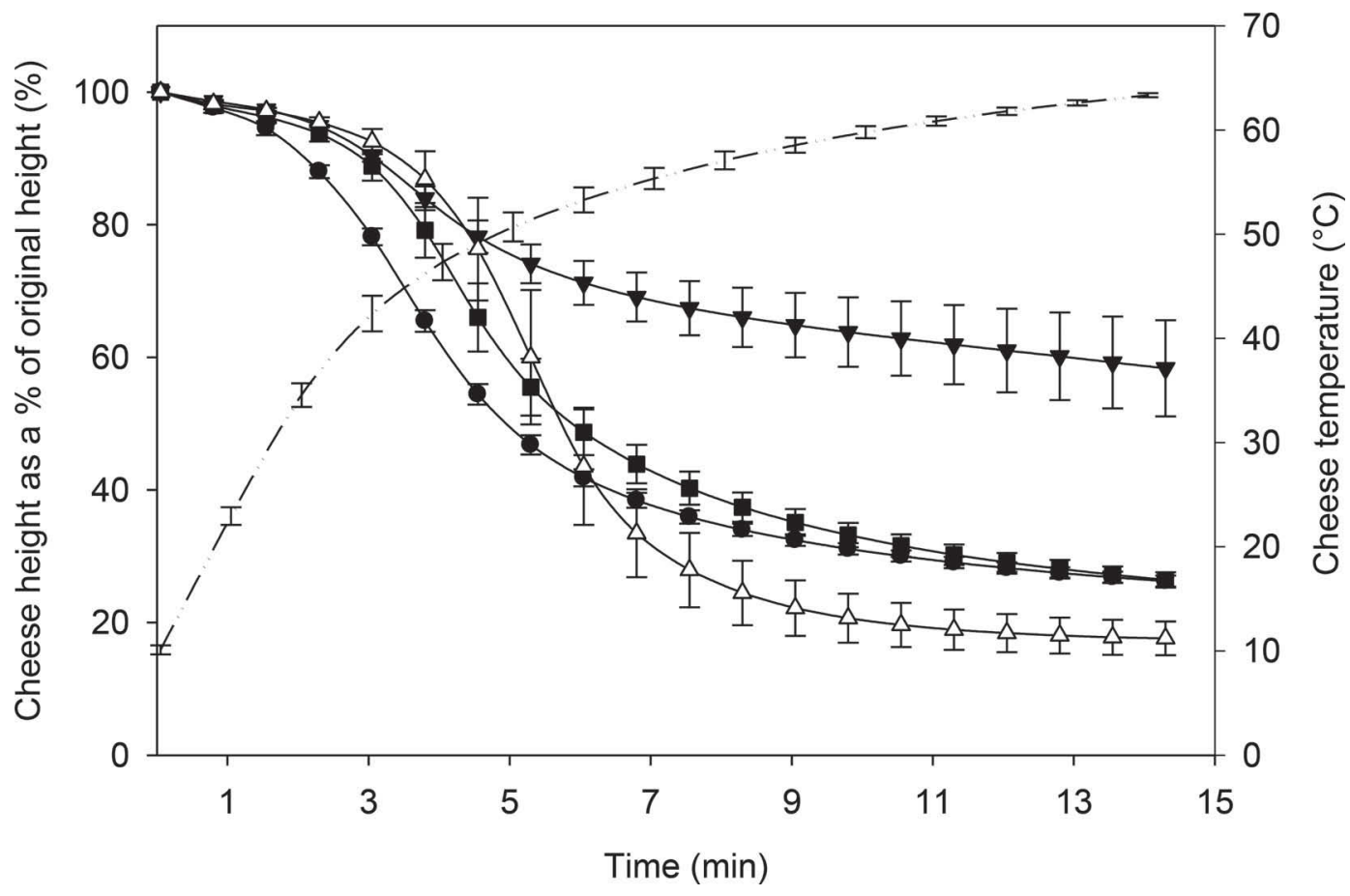

Figure 3. Changes in cheese height as a \% of the original height from the UW-Meltprofiler (University og Wisconsin-Madison) for process cheese made with various concentrations of tetrasodium pyrophosphate and natural Cheddar cheese used as an ingredient $(\Delta)$. Tetrasodium pyrophosphate concentrations: $0.25(-), 1.50(\mathbf{v})$ and $2.75 \%(\mathbf{\square})$. The data represents the means $(\mathrm{n}=3)$ whereas the error bars represent the standard deviation.

previously reported for milk protein solutions with added TSPP (Mizuno and Lucey, 2005; Ozcan et al., 2008); these previous studies suggested that the altered profiles resembled those of insoluble calcium pyrophosphate. The insoluble $\mathrm{Ca}$ as a percentage of total $\mathrm{Ca}$ increased with increasing ES concentration (Figure 4b) reflecting the chelation of $\mathrm{Ca}$ and the formation of insoluble calcium pyrophosphates with TSPP addition. The increase in the value of the maxima (peaks) observed during acid-base buffering with increasing ES concentration (e.g., Figure 5) also agrees with the suggestion of the formation of greater amounts of insoluble calcium pyrophosphate. The insoluble $\mathrm{P}$ content of process cheese, expressed as milligrams per $100 \mathrm{~g}$ of cheese, increased with increasing ES concentration (Figure 4c). However, the insoluble $\mathrm{P}$ content of process cheese, expressed as a percentage of total $\mathrm{P}$ (indigenous $\mathrm{P}$ and added $\mathrm{P}$ from TSPP), decreased with increasing ES levels (Figure 4d). This indicates that some of the added $\mathrm{P}$ (derived from this phosphate-based ES) remained in the soluble phase; a similar trend was observed with the addition of sodium hexametaphosphate (SHMP) to process cheese (Shirashoji et al., 2010). Cavalier-Salou and Cheftel (1991) reported for cheese analogs that the percentage of insoluble $\mathrm{Ca}$ increased as the concentration of TSPP was increased. Cavalier-Salou and Cheftel
(1991) also suggested that some type of insoluble calcium phosphates may have formed in the presence of TSPP. It is well known that TSPP has strong calciumbinding abilities (Van Wazer and Callis, 1958; Lucey et al., 2011), which explains the strong ability of added TSPP to bind the Ca in cheese.

Low concentrations of TSPP $(0.62 \%)$ produced process cheese that were homogeneous and without visible oil separation during reheating for the Schreiber test. This indicated that low concentrations of TSPP (even with a short holding time) was sufficient to disperse caseins during cooking. We noted increased pellet weight at low ES concentration (Figure 4a), which followed the trend of decreased meltability (Figure 2a); at ES concentrations of around 1\% the properties of process cheese had significantly changed. Process cheese samples exhibited high $\mathrm{G}^{\prime}$ values at $70^{\circ} \mathrm{C}$ (Figure 2a), indicating an elastic network remained at higher temperatures. Process cheese samples also had very low LT values (Figure $2 b$ ), which indicated less bond mobility (Lucey et al., 2003). In agreement with these rheological parameters, process cheese made with $1 \%$ ES had limited meltability (Figure 2c, d). Savello et al. (1989) studied the effect of different types of ES on a model process cheese prepared with rennet casein. They observed limited meltability with the addition of TSPP. 

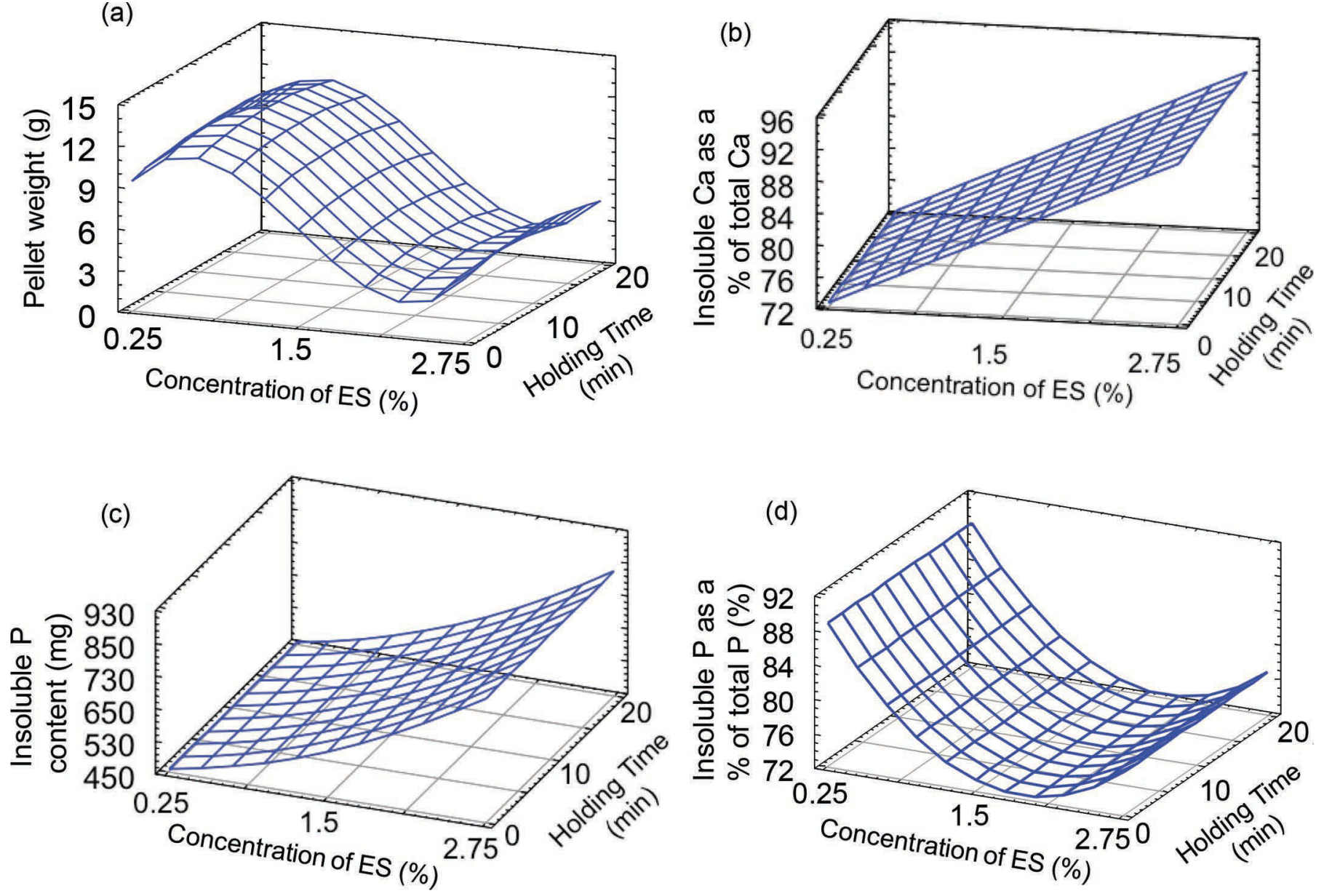

Figure 4. Response surface plots for the effect of concentrations of emulsifying salts (ES) and holding times on (a) pellet weight, (b) insoluble $\mathrm{Ca}$ as a percentage of total $\mathrm{Ca}$ in process cheese, $(\mathrm{c})$ insoluble $\mathrm{P}$ content in $100 \mathrm{~g}$ of process cheese, and (d) the insoluble $\mathrm{P}$ as a percentage of total $\mathrm{P}$ in process cheese. Color version available online.

They observed that when acid casein was used instead of rennet casein, model process cheese prepared with TSPP had excellent meltability. We presumed that in rennet casein the formation of calcium pyrophosphate complexes that were associated with the caseins might have contributed to the poor meltability, whereas the very low $\mathrm{Ca}$ content of acid casein may have caused these types of crosslinks to be absent.

At ES concentrations $>1.0 \%$, a different type of behavior was observed in process cheese samples. The $\mathrm{G}^{\prime}$ values at $70^{\circ} \mathrm{C}$ markedly decreased (Figure 2a), indicating a more viscous type of system was present at higher temperatures. Process cheese samples made with $>1.0 \%$ also had high LT values (Figure $2 \mathrm{~b}$ ), which indicated high bond mobility (Lucey et al., 2003). Both melt tests indicated improved meltability with high ES concentrations (Figure 2c, d).

Casein interactions can be viewed as a balance between attractive and repulsive forces (Horne, 1998).
Attractive forces in cheese include hydrophobic interactions, calcium phosphate cross-links, positive/ negative charge bridges, and hydrogen bonds (Lucey et al., 2003). The balance between the attractive and negative interactions in cheese appear to have been greatly modified by the specific concentration of TSPP used in process cheese. The addition of low levels of TSPP (e.g., $\leq 1 \%$ ) effectively dispersed the caseins, as indicated by the absence of any oiling off when the process cheese was subsequently reheated as well as the elevated casein pellet dispersion (Figure 4a). Mizuno and Lucey (2007), in their study of the effect of TSPP on a milk protein system, demonstrated that a critical concentration of TSPP effectively dispersed caseins, but that gelation occurred during holding of this system at room temperature. The mechanism for this gelation was suggested to be due to the formation of cross-linkages between caseins via Ca pyrophosphate complexes, or alternatively by reduction of the elec- 

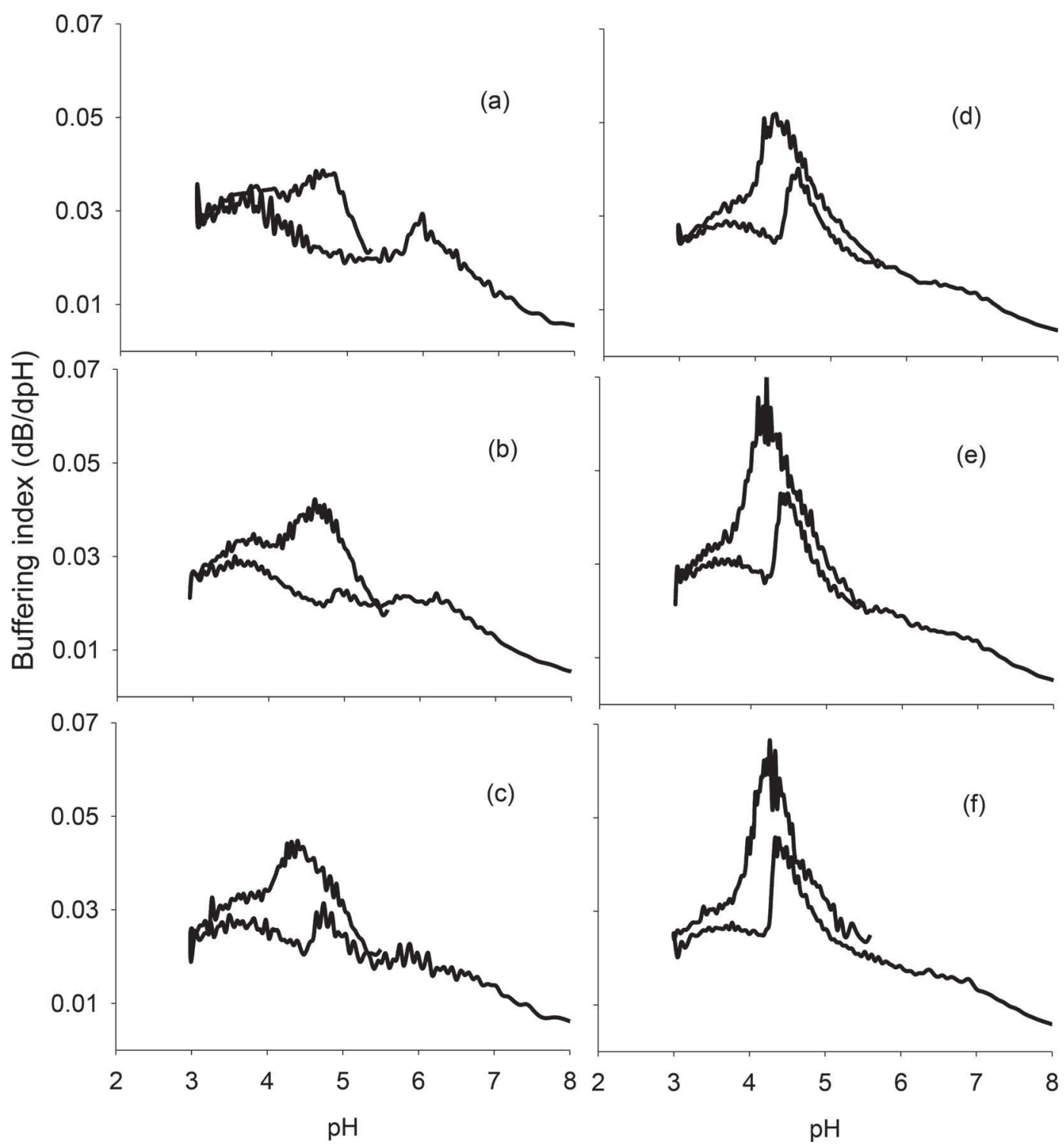

Figure 5. Acid-base buffering curves for (a) natural Cheddar cheese as a cheesemaking ingredient and process cheeses made with various tetrasodium pyrophosphate concentrations: (b) 0.25 , (c) 0.62 , (d) 1.50 , (e) 2.38 , and (f) $2.75 \%$.

trostatic repulsion between caseins, which facilitated hydrophobic association (Mizuno and Lucey, 2007). It is probable that similar mechanism(s) was responsible for the firm and poorly meltable process cheese texture that was created by low levels of TSPP addition. The association of calcium pyrophosphates complexes with dispersed caseins could reduce charge repulsion, which could also help facilitate hydrophobic interactions between hydrophobic segments of dispersed caseins.

At higher TSPP levels, weak and more meltable process cheese samples were observed. Mizuno and Lucey (2007) noted that higher TSPP usage levels prevented gelation of their milk protein system (i.e., TSPP effectively dispersed the caseins but no reassociation of caseins occurred and the system remained a stable dispersion). Mizuno and Lucey (2007) suggested that high levels of TSPP resulted in excessive anionic charge repulsion from the added pyrophosphate ions. In our process cheese samples, with an increase in TSPP usage there was an increase in the concentration of soluble $\mathrm{P}$ (decrease in insoluble $\mathrm{P}$ as a percentage of total $\mathrm{P}$; Figure 4d). The increased concentration of soluble pyrophosphate anions could contribute to enhanced charge repulsion in the process cheese system.

In previous studies of process cheese made with the trisodium citrate (Shirashoji et al., 2006) and sodium hexametaphosphate (Shirashoji et al., 2010), no complex ES concentration-dependent behavior was 
observed for process cheese properties. For these types of $\mathrm{ES}$, the $\mathrm{G}^{\prime}$ values at $70^{\circ} \mathrm{C}$ increased with increasing ES concentration and meltability decreased (Shirashoji et al., 2006, 2010). Thus, TSPP appears to have unique characteristics that are responsible for the complex behavior observed in process cheese. It has been reported that certain concentrations of TSPP can induce creaming, whereas neither trisodium citrate nor sodium hexametaphosphate are considered ES that have strong creaming ability (Berger et al., 1998; Maurer-Rothmann and Scheurer, 2005). No obvious creaming was observed in any of our process cheese samples. Neither trisodium citrate nor sodium hexametaphosphate were effective at the gelation of milk proteins even though they could disperse the caseins (Mizuno and Lucey, 2007). The trend of increased meltability of process cheese with high levels of TSPP was not observed with other types of ES (trisodium citrate and sodium hexametaphosphate; Shirashoji et al., 2006, 2010). It was the occurrence of a critical ES concentration where stiffness increased and meltability decreased that was a unique behavior to TSPP. Mizuno and Lucey (2007) suggested that the diphosphate TSPP molecule was better able to bridge or crosslink casein molecules than other types of phosphate-based ES, which could explain some of its unique characteristics.

\section{CONCLUSIONS}

The concentration of TSPP used in process cheese resulted in complex textural and melting behavior. Addition of TSPP resulted in the formation of calcium pyrophosphate complexes. Low levels of TSPP resulted in process cheeses that were stiff and poorly meltable. We hypothesized that low levels of pyrophosphate helped crosslink the dispersed caseins. Meltability increased and stiffness decreased with higher TSPP levels, likely due to excessive charge repulsion among dispersed caseins.

\section{ACKNOWLEDGMENTS}

The National Dairy Council (Rosemont, IL) is thanked for partial support for this project.

\section{REFERENCES}

Awad, R. A., L. B. Abdel-Hamid, S. A. El-Shabrawy, and R. K. Singh. 2002. Texture and microstructure of block type processed cheese with formulated emulsifying salt mixtures. LWT Food Sci. Technol. 35:54-61.

Berger, W., H. Klostermeyer, K. Merkenich, and G. Uhlmann. 1998. Process Cheese Manufacture-A JOHA Guide. BK Giulini Chemie Gmbh \& Co. OHG, Ladenburg, Germany.
Carić, M., M. Gantar, and M. Kalab. 1985. Effect of emulsifying agents on the microstructure and other characteristics of process cheese. Food Struct. 4:297-312.

Cavalier-Salou, C., and J. C. Cheftel. 1991. Emulsifying salts influence on characteristics of cheese analogs from calcium caseinate. J. Food Sci. 56:1542-1547., 1551.

Cunha, C. R., and W. H. Viotto. 2010. Casein peptization, functional properties, and sensory acceptance of processed cheese spreads made with different emulsifying salts. J. Food Sci. 75:C113-120.

Dimitreli, G., A. S. Thomareis, and P. G. Smith. 2005. Effect of emulsifying salts on casein peptization and apparent viscosity of processed cheese. Int. J. Food Eng. 1:1-15.

Guinee, T. P., M. Caric, and M. Kalab. 2004. Pasteurized processed cheese and substitute/imitation cheese products. Pages 349-394 in Cheese: Chemistry, Physics and Microbiology. vol. 2. 3rd ed. P. F. Fox, ed. Elsevier, London, UK.

Gupta, S. K., C. Karahadian, and R. C. Lindsay. 1984. Effect of emulsifier salts on texture and flavor properties of processed cheeses. J. Dairy Sci. 67:764-778.

Hassan, A., M. E. Johnson, and J. A. Lucey. 2004. Changes in the proportions of soluble and insoluble calcium during the ripening of Cheddar cheese. J. Dairy Sci. 87:854-862.

Horne, D. S. 1998. Casein interactions: Casting light on the black boxes, the structure in dairy products. Int. Dairy J. 9:261-268.

Kawasaki, Y. 2008. Influence of "creaming" on the properties of processed cheese and changes in the structure of casein during cheese making. Milchwissenschaft 63:149-152.

Lu, Y., N. Shirashoji, and J. A. Lucey. 2008. Effects of pH on the textural properties and meltability of pasteurized process cheese made with different types of emulsifying salts. J. Food Sci. 73:E363-369.

Lucey, J. A., and P. F. Fox. 1993. Importance of calcium and phosphate in cheese manufacture: A review. J. Dairy Sci. 76:1714-1724.

Lucey, J. A., M. E. Johnson, and D. S. Horne. 2003. Perspectives on the basis of the rheology and texture properties of cheese. J. Dairy Sci. 86:2725-2743.

Lucey, J. A., A. Maurer-Rothmann, and S. Kaliappan. 2011. Functionality of ingredients: Emulsifying salts. Pages 110-132 in Processed Cheese and Analogues. A. Y. Tamime, ed. Wiley-Blackwell, West Sussex, UK.

Marchesseau, S., E. Gastaldi, A. Lagaude, and J.-L. Cuq. 1997. Influence of $\mathrm{pH}$ on protein interactions and microstructure of process cheese. J. Dairy Sci. 80:1483-1489.

Marshall, R. T. 1992. Standard Methods for the Examination of Dairy Products. 16th ed. Am. Public Health Assoc., Washington, DC.

Maurer-Rothmann, A., and G. Scheurer. 2005. Stabilization of Milk Protein Systems: A JOHA Guide. BK Giulini GmbH, Ladenburg, Germany.

Meyer, A. 1973. Processed Cheese Manufacture. Food Trade Press Ltd., London, UK.

Mizuno, R., and J. A. Lucey. 2005. Effects of emulsifying salts on the turbidity and calcium-phosphate-protein interactions in casein micelles. J. Dairy Sci. 88:3070-3078.

Mizuno, R., and J. A. Lucey. 2007. Properties of milk protein gels formed by phosphates. J. Dairy Sci. 90:4524-4531.

Montgomery, D. C. 2001. Design and Analysis of Experiments. 5th ed. John Wiley, New York. NY.

Mulsow, B. B., D. Jaros, and H. Rohm. 2007. Processed cheese and cheese analogues. Pages 210-235 in Structure of Dairy Products, A. Y. Tamime, ed. Blackwell, Oxford, UK.

Muthukumarappan, K., Y.-C. Wang, and S. Gunasekaran. 1999a. Modified Schreiber test for evaluation of Mozzarella cheese meltability. J. Dairy Sci. 82:1068-1071.

Muthukumarappan, K., Y.-C. Wang, and S. Gunasekaran. 1999b. Estimating softening point of cheeses. J. Dairy Sci. 82:2280-2286.

Nagyová, G., F. Buňka, R. N. Salek, M. Černíkavá, P. Manćík, T. Gruber, and D. Kuchar. 2014. Use of sodium polyphosphates with different linear lengths in the production of spreadable processed cheese. J. Dairy Sci. 97:111-122.

Ozcan, T., J. A. Lucey, and D. S. Horne. 2008. Effect of tetrasodium pyrophosphate on the physicochemical properties of yogurt gels. J. Dairy Sci. 91:4492-4500. 
Rayan, A. A., M. Kalab, and C. A. Ernstrom. 1980. Microstructure and rheology of process cheese. Scan. Electron Microsc. III:635643.

Sádlíková, I., F. Buňka, P. Budinský, V. Barbora, V. Pavlínek, and I. Hoza. 2010. The effect of selected phosphate emulsifying salts on viscoelastic properties of processed cheese. LWT Food Sci. Technol. 43:1220-1225.

Salek, R. N., M. Černíková, G. Nagyová, D. Kuchař, H. Bačová, L. Minarčíková, and F. Buňka. 2015. The effect of composition of ternary mixtures containing phosphate and citrate emulsifying salts on selected textural properties of spreadable processed cheese. Int. Dairy J. 44:37-43

Savello, P. A., C. A. Ernstrom, and M. Kalab. 1989. Microstructure and meltability of model cheese made with rennet and acid casein. J. Dairy Sci. 72:1-11.
Shirashoji, N., J. J. Jaeggi, and J. A. Lucey. 2006. Effect of sodium trisodium citrate concentration and cooking time on the physicochemical properties of pasteurized process cheese. J. Dairy Sci. $89: 15-28$.

Shirashoji, N., J. J. Jaeggi, and J. A. Lucey. 2010. Effect of sodium hexametaphosphate concentration and cooking time on the physicochemical properties of pasteurized process cheese. J. Dairy Sci. 93:2827-2837.

Templeton, H. L., and H. H. Sommer. 1930. Some observations on processed cheese. J. Dairy Sci. 13:203-220.

Van Wazer, J. R., and C. F. Callis. 1958. Metal complexing by phosphates. Chem. Rev. 58:1011-1046. 